\title{
OWNERSHIP INFLUENCE ON USE OF FUNDING SOURCES IN CONDITIONS OF THE CZECH REPUBLIC
}

\author{
[Vliv vlastnictví na využití zdrojů financování v podmínkách České republiky]
}

\author{
Michaela Roubíčková ${ }^{1}$, Petra Růčková ${ }^{2}$ \\ ${ }^{1}$ Slezská univerzita, Obchodně podnikatelská fakulta, Univerzitní nám. 1934/3, 73340 Karviná \\ Email:roubickova@opf.slu.cz \\ ${ }^{2}$ Slezská univerzita, Obchodně podnikatelská fakulta, Univerzitní nám. 1934/3, 73340 Karviná \\ Email:ruckova@vsb.cz
}

\begin{abstract}
Not only developing countries and transition economies perceive the entry of foreign investors, and the inflow of capital, know -how and other tangible and intangible assets as a catalyst for economic development. Therefore, many countries have liberalized access to foreign capital even conscious of certain negative effects on domestic enterprises trying to attract foreign investors. The host countries after some time analyse the contribution and influence of foreign entities in the domestic economy and assesses whether the resulting effects rather negative or positive, and also how foreign entities are operating in the domestic territory. This article, however, deals with a somewhat different type of analysis, it focuses on the assessment of the functioning and prosperity of foreignowned entities in the Czech Republic compared with domestic entities in selected sectors. The analysis is focused on the development of return on equity (ROE) and gross domestic product (GDP) of industries. The data from the Financial analyzes of the corporate sector for the years $2004-2011$ published by the Ministry of Industry and Trade was used to analyze. It was the annual data (including GDP) in five sectors: mining, manufacturing, energy, construction and services.
\end{abstract}

Keywords: foreign direct investment, foreign majority owner, gross domestic product, home majority owner, return on equity, subsector.

JEL classification: G32, F23

Doručeno redakci: 25.4.2013; Recenzováno: 1.7.2013; 20.6.2013; Schváleno k publikování: 16.6.2014

\section{Úvod}

Za stěžejní aspekt pro provedenou analýzu bylo považováno většinové vlastnictví podniků v daném odvětví, tedy institucionální sektor. Institucionální sektor představuje soubor institucionálních jednotek, které jsou charakteristické podobným zaměřením a cíli a slouží $\mathrm{k}$ analýze tvorby a rozdělování důchodu. Sektory jsou dále rozdělovány na podsektory. $\mathrm{V}$ př́padě nefinančních podniků, o kterých pojednává tento článek, je toto členění prováděno v závislosti na subjektu, který je kontroluje a ovládá. Jsou proto rozlišovány podniky pod státní kontrolou, soukromé podniky pod domácí kontrolou a soukromé podniky pod zahraniční kontrolou. Rozdělení do jednotlivých podsektorů nelze sice provést zcela přesně, protože podsektory se v některých případech vzájemně prolínají a část podniků národního veřejného a soukromého sektoru může být vlastněna zahraničním vlastníkem, ale i tak má poměrně značnou vypovídací schopnost.

Vzhledem $\mathrm{k}$ tomu, že tento článek je zaměřen na porovnání ekonomických parametrů soukromých podniků pod domácí kontrolou a soukromých podniků pod zahraniční kontrolou (podniky pod státní kontrolou jsou z analýzy zcela vynechány), existuje zde jednoznačná souvislost $\mathrm{s}$ přímými zahraničními investicemi (FDI). Přímé zahraniční investice je možné vnímat jednak z pohledu vkladu do základního kapitálu společnosti, ale také jako reinvestici generovaného zisku. Pro účely tohoto článku však nebudeme mezi těmito dvěma kategoriemi rozlišovat, nebot' je analyzován vliv těchto investic na efektivnost podniků. 


\section{Př́mé zahraniční investice do vybraných ekonomických sektorů}

Klady a zápory FDI mohou být diskutovány $\mathrm{v}$ různém kontextu, empirické studie ale zpravidla prokazují, že FDI jsou př́nosem pro zvýšení výkonu firem, průmyslu a makroekonomických ukazatelů. FDI přináší výhody hostitelské zemi prostřednictvím několika kanálů. Kromě samotného př́livu kapitálu jsou FDI obvykle spjaty s pohybem specifických hmotných i nehmotných aktiv jako jsou technologie, manažerské schopnosti a dovednosti, corporate governance, ale také například př́stup $\mathrm{k}$ síti firem spojujících na zahraničních trzích. Jakmile zahraniční investor dosáhne určité úrovně vlastnictví podniku v hostitelské zemi a získá kontrolu nad řízením firmy, je pak ochoten poskytovat pro zahraniční firmu specifická aktiva, jejichž využití by mělo znamenat zvýšení profitability bez ohledu na to, jestli se jednalo o firmu vybudovanou na zelené louce či firmu ovládnutou pomocí mikroekonomické integrace. Jak uvádí např́iklad Economic Survey of Europe ${ }^{1}$, FDI jsou právě $\mathrm{z}$ tohoto důvodu často považovány za důležitý katalyzátor ekonomické transformace transitivních ekonomik.

Za př́mou zahraniční investici je možné označit takovou, v níž zahraniční investor vlastní 10 a více procent akcií (podílu) nebo hlasovacích práv. Za součást přímé zahraniční investice je považován kromě podílu na základním kapitálu také reinvestovaný zisk a ostatní kapitál, jenž zahrnuje úvěrové vztahy se zahraničním investorem. Pokud tento podíl nepřesahuje $50 \%$, jsou podniky se zahraniční majetkovou účastí zahrnuty do veřejného nebo soukromého národního sektoru (Spěváček, 2010)[19]. Zahraniční kontrola je tedy definována jako př́má nebo nepř́má (přes propojené subjekty) kontrola více než poloviny hlasovacích práv akcionářu nebo více než poloviny akcií. Kontrolující země je určena podle sídla vrcholné kontrolní institucionální jednotky. Tou je společnost, která již není dále sama kontrolována jinou institucionální jednotkou (Myers, 1984).

Př́liv přímých investic do české ekonomiky jako celku má kolísavý trend. Např́íklad v letech 1999-2002 se zvyšoval každoročně v průměru zhruba o desetinu (i při relativně vysokých základních hodnotách $\mathrm{z}$ předchozího roku), když průměrný roční př́liv v tomto období činil 225,9 mld. korun. Tyto úrovně znamenaly světový primát ČR v objemu přijatých investic na obyvatele. Reinvestované zisky pak narůstaly $\mathrm{v}$ uvedených letech každoročně $\mathrm{v}$ průměru o $41 \%$. V roce 2003 však došlo k výraznému meziročnímu poklesu přímých zahraničních investic o $74 \%$, zatímco pokles objemu reinvestovaných zisků činil pouze 1,7 \%. 2003 prímé investice dosáhly výše 72,9 mld. V roce 2005 došlo $\mathrm{z}$ tehdejšího pohledu $\mathrm{k}$ historicky nejvyššímu př́livu zahraničních investic do české ekonomiky s čistým saldem 279,2 mld. Kč - z toho kapitálové vstupy a reinvestované zisky dosáhly 262,5 mld. Kč, zbytek činily ostatní investice. Přímé zahraniční investice do ČR v roce 2006 byly meziročně nižší o 144,5 mld. Kč (tj. o $52 \%$ ). Kapitálové vstupy do českých podniků klesly o 148,8 mld. Kč. Zahraniční investoři však investovali zpět do podnikatelské činnosti na území České republiky zisky ve výši 82,1 mld. Kč, což představovalo o 4 mld. Kč více než v roce 2005.

Obrázek 1 prezentuje prŕliv prrímých zahraničních investic do vybraných sektorů v letech 2004 - 2011 dle údajů ČNB. Do roku 1997 zahrnovaly údaje pouze přímé zahraniční investice do základního kapitálu, od roku 1998 jsou součástí i reinvestované zisky a ostatní kapitál. Z obrázku je zřejmé, že největší př́liv FDI zaznamenal zpracovatelský průmysl (meziročně v roce 2007), kde je též patrný největší meziroční propad v letech 2008 a 2009, a to -64575 mil Kč a -50540 mil Kč, což právě v roce 2009 představovalo $-365 \%$. Podobný

\footnotetext{
${ }^{1}$ Economic survey of Europe No. 1. [online] New York: United Nations, 2001. [vid. 2013-01-02]. Dostupné z http://www.unece.org/fileadmin/DAM/ead/pub/011/011_0.pdf.
} 
trend můžeme nalézt i u služeb. Trend $\mathrm{v}$ těchto odvětvích se odlišuje až v roce 2011. V ostatních třech sledovaných odvětvích nebyly výkyvy tak výrazné.

Obrázek 1: Př́liv př́mých zahraničních investic do vybraných sektorů v letech 2004 - 2011 (v mld. Kč)

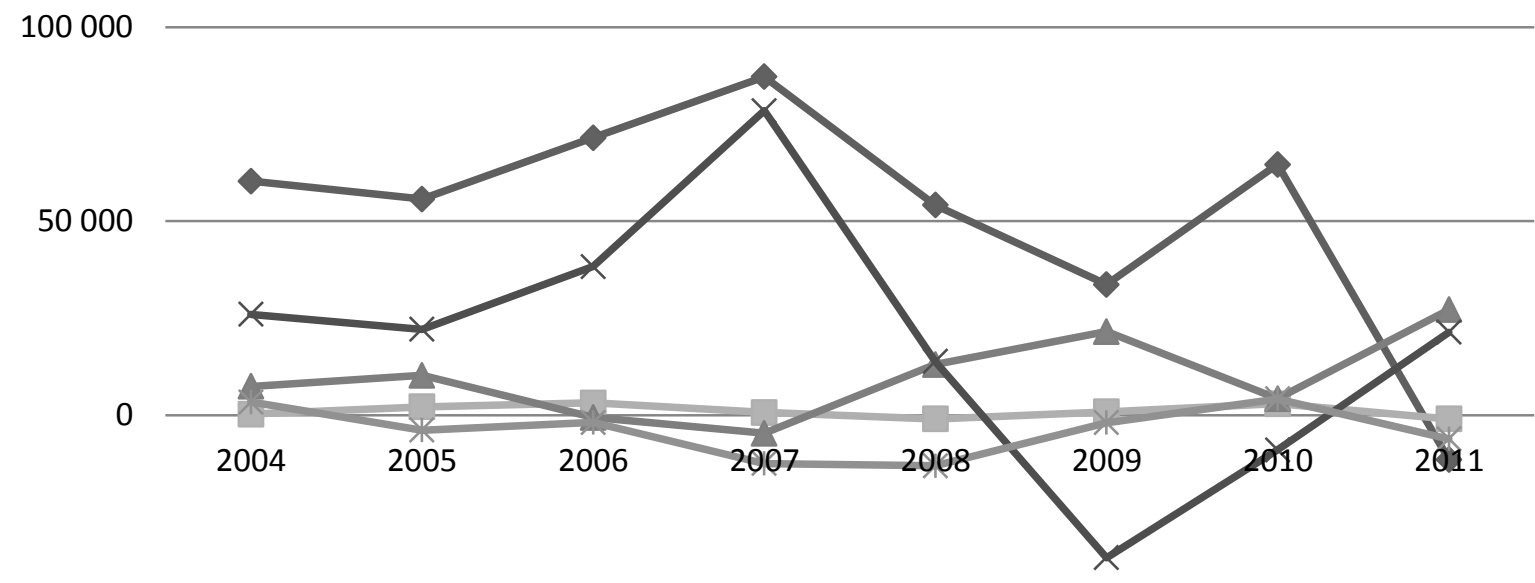

$-50000$

—Služby -Stavebnictví —Energetika $\longleftarrow$ Zpracovatelský průmysl *Dobývání

Zdroj: ČNB - Př́liv přímých zahraničních investic podle sektorů a zemí - časová řada

\section{Empirická evidence}

Vlivem FDI na vybrané (nikoli makroekonomické) ukazatele se zabývá řada studií. Velká část je přitom zaměřena na efekty působící na domácí podniky, které způsobuje odliv FDI ze země. Řada dalších pak sleduje např́iklad vliv přílivu FDI na počet zaměstnanců a výši mezd (např́klad Demel a Potužáková, 2012). Existují však i studie, které se (podobně jako tento článek) zabývaly vlivem př́mých zahraničních investic na rentabilitu společností. Studie pocházejí z různých oblastí světa, které se liší nejen ekonomickou vyspělostí, ale rovněž např́iklad typem finančního systému a tím i typem dominujícího modelu vlastnické struktury. Česká republika je, jak uvádí např́íklad Roubíčková (2008), typickou kontinentálněevropskou zemí, kde existuje silný bankovní sektor a kapitálový trh není stěžejním zdrojem finančních prostředků (v současnosti - březen 2013 - je na BCPP umístěno 30 titulů akcií). Kontinentálně-evropský model ř́źzení je zároveň charakteristický insider systém, který představuje vyšší úroveň vlivu na řízení společnosti zevnitř. Tato skutečnost je možná proto, že v tomto systému existuje možnost (a podmínky) pro vznik majoritního či významného vlastnictví. Ve sledovaném období bylo ve vybraných ekonomických sektorech takřka dvojnásobek ekonomicky aktivních společností se zahraničním majoritním vlastníkem nežli s domácím.

Z kontinentálně-evropské oblasti lze uvést například výzkumy Arndta a Mattese (2008), kteří porovnávali velikost a produktivitu domácích a zahraničních německých společností a došli k závěru, že zahraniční MNC jsou menší a produktivnější. Zaměstnanost v MNC byla o $15 \%$ nižší, zatímco celkový faktor produktivity (TFP) vykázaly o 5,6 \% ař $6.5 \%$ vyšší. Produktivita pracovní síly MNC byla pak dokonce o $20 \%$ vyšší. Dále prokázali, že zatímco efekt vlastnické změny na zaměstnanost není signifikantní, efekt změny na produktivitu pracovní síly a celkovou produktivitu je pozitivní. Naproti tomu studie Gelübcke (2011) prokázala, že zahraničně kontrolované společnosti ze sektoru služeb podnikající v Německu 
jsou charakteristické o $50 \%$ vyšší zaměstnaností, o více než 60 \% vyššími mzdami a o $2 \%$ až 6\% nižšśi rentabilitou tržeb ve srovnání s domácími společnostmi.

K zemím kontinentálně-evropského systému je řazeno též Japonsko. Zde se Sakakibara a Yamawaki (2005) zaměřili na sledování determinant rentability dceřiných společností japonských multinacionálních firem v letech 1990 - 1996. Výsledky jejich výzkumu ukázaly, že se determinanty mající vliv na rentabilitu dceřiných společností liší v závislosti na hostitelské zemi. To naznačuje, že ekonomické a institucionální faktory specifické pro hostitelské regiony mohou významně ovlivnit výkony rentabilitu zahraničních poboček. Na rozdíl od velikosti, která má vliv na dceřinou ziskovost signifikantně ve všech zemích, jiné efekty jako jsou zkušenosti, místní dodavatelské sítě, lokální prodejní a makroekonomické podmínky ovlivňují výkon dceřiných společností odlišným způsobem podle hostitelské země.

Z hlediska České republiky jsou důležité též studie provedené $\mathrm{v}$ transformujících se ekonomikách. Např́klad Yasar a Paul (2007) porovnávali ve své analýze výkonnost společností se zahraniční majetkovou účastí oproti výkonnosti čistě domácích průmyslových firem. Pro analýzy použili data za pět transformujících se ekonomik, a to Polska, Moldávie, Tádžikistánu, Uzbekistánu a Kyrgyzstánu. Jednoznačně zjistili, že zahraničně vlastněné společnosti vykazují vyšší produktivitu, intenzitu využití kapitálu, podíl vývozu a dovozu, úroveň zaměstnanosti a mezd. Dále zjistili, že průmysl s př́tomností zahraničních poboček nadnárodních společností vykazuje zlepšení výkonnosti u domácích firem. Tato zjišsění podporují hypotézu, že zahraniční firmy s sebou přinášejí technologie a dovednosti, prrístup na zahraniční trhy a nové pracovní př́ležitosti, které zvyšují výkonnost firem hostitelské země. To zase naznačuje, že spojení se zahraničně vlastněnými firmami by mělo být podporováno, protože vede ke zvýšení produktivity a konkurenceschopnosti průmyslu v transformujících se ekonomikách. Szanyi (1998) pak ve své studii udává, že u společností se zahraničním vlastníkem podnikajících v Mad’arsku se zejména v prvních letech po investici vyskytovaly horší finanční výsledky než u společností domácích.

Z výše uvedeného textu je zřejmé, že bylo publikováno velké množství empirických studií zabývajících se celou řadou otázek spojených s FDI. Jak ale uvádí Jarolím (2000), je poměrně zarážející, že jen málo z nich se věnuje vlivům FDI na země střední a východní Evropy, přestože prŕliv zahraničního kapitálu byl považován za jeden z klíčových faktorů vývoje transformačního procesu. Autor ve své vlastní studii analyzoval údaje za sektor zpracovatelského průmyslu v letech 1993-1998. Zaměřil se na porovnání ukazatelů charakterizujících produktivitu práce, vnější orientaci a investiční aktivity u společností se zahraničním a domácím vlastníkem a snažil se nalézt odpověd' na otázku, která skupina dosahuje většího tempa růstu výrobních faktorů. Dalším cílem bylo zkoumání existence spillover efektu. Jeho výsledky ukázaly, že firmy se zahraniční účastí dosahují vyšší produktivity práce, exportují větší část výroby a investují větší množství prostředků $\mathrm{k}$ celkovým prodejům. Tyto závěry však platí pouze tehdy, jestliže není brána v potaz velikost firem. V opačném případě výsledky ukazují, že zahraniční firmy dosahují pouze $90 \%$ úrovně produktivity. Existenci spillover efektu se autorovi prokázat nepodařilo.

V podmínkách České republiky byl proveden též výzkum autory Hanouskem, Kočendou a Švejnarem (2005). Z jejich analýzy (provedené za roky 1996-1999) vyplynulo, že u výkonnosti podniků privatizovaných $\mathrm{v}$ rámci velké privatizace nehraje typ vlastnictví významnou roli. Autoři berou v potaz nejen soukromé zahraniční a domácí vlastnictví, ale též vlastnictví státní. Dle jejich názoru má koncentrované zahraniční pozitivní vliv pouze tehdy, jedná-li se o podniky průmyslové, přičemž koncentrované zahraniční vlastnictví zvyšuje 
tržby, zatímco víceméně stejně koncentrované domácí vlastnictví v uvedeném období naopak snižovalo náklady na pracovní sílu. Autoři analyzovali společnosti, jejichž akcie byly obchodovány na Burze cenných papírů Praha v letech 1996.

Za použití rozsáhlého panelu dat analyzovali v období 1996-2007 skutečnost, jak je podniková efektivita ovlivněna vlastnickou strukturou také Hanousek, Kočanda a Mašika (2012). Výsledky podpořily hypotézu, že koncentrované a zahraniční vlastnictví jsou kladně provázány $\mathrm{s}$ efektivitou a že prŕmé zahraniční investice vykazují kladný vliv na podniky na mikroekonomické úrovni.

Porovnání výkonnosti firem před a po převzetí provedli Jurajda a Stančík (2009). Autoři považovali za zahraničně vlastněné ty společnosti, kde zahraniční subjekt disponoval více než $10 \%$ podílem na základním kapitálu. Sledováno bylo více než 4.000 společností ze zpracovatelského průmyslu v letech 1995-2005, důležitým mezníkem byl rok 1997, kdy došlo $\mathrm{k}$ převzetí řady firem po ukončení privatizace. $Z$ analýzy vyplynulo, že vliv vstupu zahraničního kapitálu je pozitivní zejména $\mathrm{v}$ neexportních oblastech zpracovatelského průmyslu. V ostatních oblastech je pak jeho vliv malý.

Vlivem existence zahraničního vlastníka na vybrané ukazatele podniků se ve svém výzkumu zabývala též Roubíčková (2012). Cílem článku bylo vyhodnotit vliv príslušnosti $\mathrm{k}$ institucionálnímu subsektoru na vývoj rentability a zadluženosti podniků $\mathrm{z}$ odvětví stavebnictví. Byl proto analyzován a porovnán vývoj ukazatelů podniků se zahraničním a domácím vlastníkem od počátku roku 2007 až do poloviny roku 2011. Analýza ukázala, že ROE soukromých podniků pod zahraniční kontrolou oproti očekávání není dlouhodobě vyšší, než soukromých podniků s domácí kontrolou. Dokonce se ani neprokázalo, že by tyto podniky dlouhodobě přinášely svým vlastníkům vyšší prridanou hodnotu. Přestože podíl vlastního kapitálu k celkovým aktivům byl u podniků pod zahraniční kontrolou dlouhodobě nižší (využívají tedy levnější finanční zdroje), nevede tato skutečnost jednoznačně k vyšší rentabilitě. $Z$ tohoto pohledu je zajímavé sledovat, zda cizí zdroje financování vedou skutečně k posílení rentability vlastního kapitálu.

Otázka načasování získávání různých druhů financování vede $\mathrm{k}$ domněnce, že pokud neexistuje funkční pákový efekt, pak to znamená, že kapitálová struktura bud' nemá vliv na efektivnost společnosti, nebo jsou náklady na změnu kapitálové struktury př́liš vysoké. Podle teorie hierarchického pořádku Myers (1984) konstatuje, že informační asymetrie vede ke skutečnosti, že realizace dodatečného financování prostřednictvím majetkových cenných papírů by měla být pouze krajní možností. Z tohoto pohledu by při financování investic měly mít primární úlohu reinvestice zadrženého zisku a nástroje dluhového financování. Nicméně jak tvrdí Hrdý (2011) není totiž možné jednoznačně určit, zda je prvotní financování interními zdroji výsledkem pohodlnosti manažerů či jejich racionálním uvažováním, protože využití interních zdrojů je na jedné straně skutečně pohodlné, nicméně na straně druhé je získávání právě externích zdrojů spojeno $\mathrm{s}$ poměrně značnými dodatečnými náklady a náročným přesvědčováním investorů o tom, že podnik je finančně zdravý a že se vyplatí do něho investovat.

Podle Stulze (1990) je optimální kapitálová struktura determinována vyvážením př́nosů využití dluhu u očekávaných investic při klesajícím počtu realizovaných investic a nákladů využití dluhu při rostoucím počtu investic. Již Jensen (1986) uvedl, že firmy, které mají dostatek vhodných (dobrých) investičních příležitostí zpravidla v menší míře využívají dluhové financování v porovnání s ,nedospělými“ firmami a firmami rozvíjejícími se. Nad to 
Stulz argumentuje, že manažeři nebudou ochotni zvyšovat podíl dluhové financování, pokud nebude existovat hrozba př́padného převzetí. Firmy s vyšší pravděpodobností převzetí vykazují mnohem vyšší úroveň dluhu než firmy, u nichž taková hrozba neexistuje. $Z$ toho tedy také plyne, že existují-li ve firmě dostatečné investiční př́ležitosti, budou mít firmy daleko méně pravděpodobně ochotu vyhledávat financování prostřednictvím dluhu a naopak firmy s nízkou úrovní investičních př́ležitostí budou dluhové financování vyhledávat.

\section{Analýza vlivu existence zahraničního vlastníka na rentabilitu ekonomického subsektoru}

Analýza vlivu existence zahraničního vlastníka na rentabilitu ekonomického subsektoru byla tedy, jak už bylo zmíněno výše, provedena v pěti sledovaných odvětvích: služby, stavebnictví, energetika, zpracovatelský průmysl a dobývání. Z hlediska základního členění podniků do jednotlivých oborů podnikání mají co do počtu až do roku 2009 nejvyšší podíl podniky zpracovatelského průmyslu, které tvořily více než $60 \%$ podílu na celku. Zpracovatelský průmysl také zaznamenal největší prríliv FDI ze sledovaných odvětví v letech 2006 a 2007 a naopak i meziroční propad v letech 2008 a 2009, a to -64575 mil Kč a -50540 mil Kč, což právě v roce 2009 představovalo -365 \%. Druhou největší skupinou podniků jsou služby, které největší př́liv FDI zaznamenaly také v letech 2006 a 2007, ale poté ještě v roce 2010.

$\mathrm{Z}$ důvodu zachování kontinuity časových řad pro zpracovávanou analýzu, byla určitá část oborů pro posledních pět let agregována. Nejproblematičtější se z hlediska přechodu z OKEČ na CZ-NACE se jeví oblasti služeb a oblast energetiky, v nichž jsou zaznamenány nejzásadnější změny. V rámci služeb je nejvíce podniků registrováno v oboru s kódovým označením $\mathrm{G}$-Velkoobchod a maloobchod, opravy a údržba motorových vozidel a obor s kódovým označením L - Činnosti v oblasti nemovitostí. Ostatní obory podnikání mají jen relativně malý podíl. Do analýzy nebyly zahrnuty finanční společnosti, nebot' nároky na výsledky analýz poměrových ukazatelů v tomto oboru podnikání vykazují jiné parametry než u běžných podnikatelských činností. Struktura se však v roce 2010 změnila mírně ve prospěch oblasti služeb. Lze říci, že takový podíl není zcela obvyklý a je závislý na zaměření ekonomických činností v rámci specifik jednotlivých teritorií. (Růčková, 2012).

Obrázek 2: Struktura oborů podnikání v rámci české ekonomiky u podniků s domácími vlastníky v letech 2004 až 2011

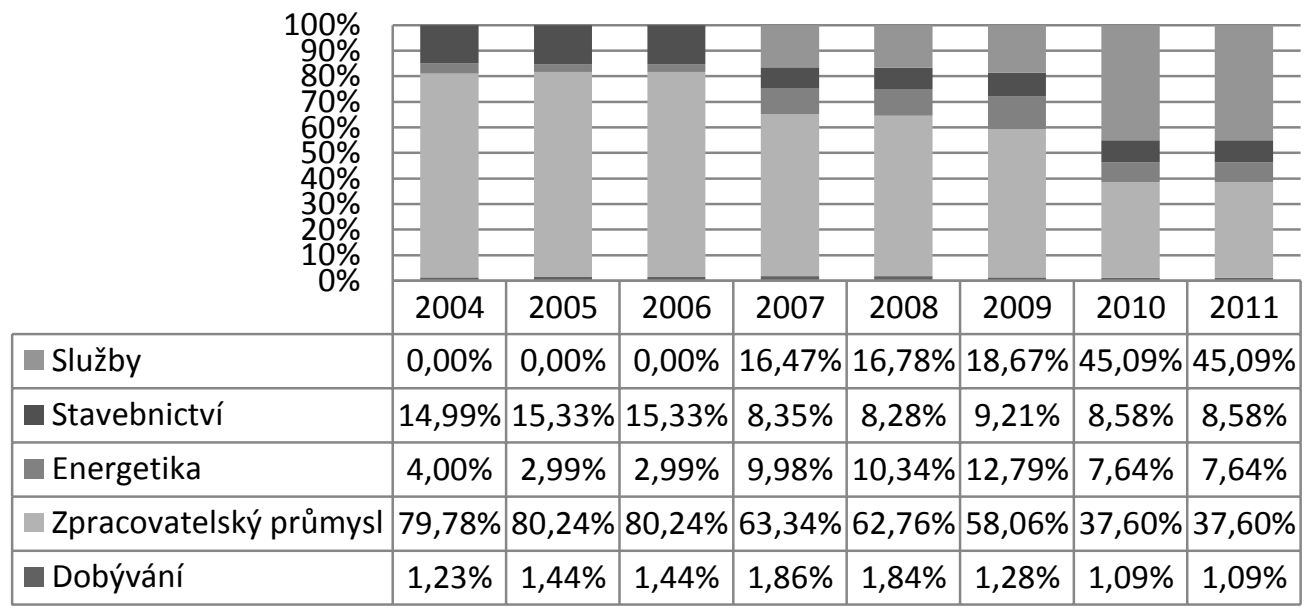

Zdroj: vlastní na podkladu oborových analýz Ministerstva průmyslu a obchodu ${ }^{2}$

\footnotetext{
2 Server of Ministry of Industry and Trade of the Czech Republic. [online] Praha, 2012 [vid. 2013-01-02] Url: http://www.mpo.cz, Finanční analýzy Ministerstva průmyslu a obchodu České republiky.
} 
Zaměříme-li svou pozornost na strukturu podniků podle většinového vlastníka, pak tuto skutečnost dokumentují Obrázek 2 a Obrázek 3. U společností, které jsou vlastněny domácím investorem, je struktura oborů podnikání podobná rozložení oborů podnikání jako celku. Mírně vyšší procento lze nalézt u společností ve stavebnictví a v energetice, naopak menší podíl má zpracovatelský průmysl. Avšak podobně jako v celkovém pohledu však převahu na celkové struktuře získávají služby až od roku 2010.

Obrázek 3: Struktura oborů podnikání v rámci české ekonomiky u podniků se zahraničními vlastníky v letech 2004 až 2011

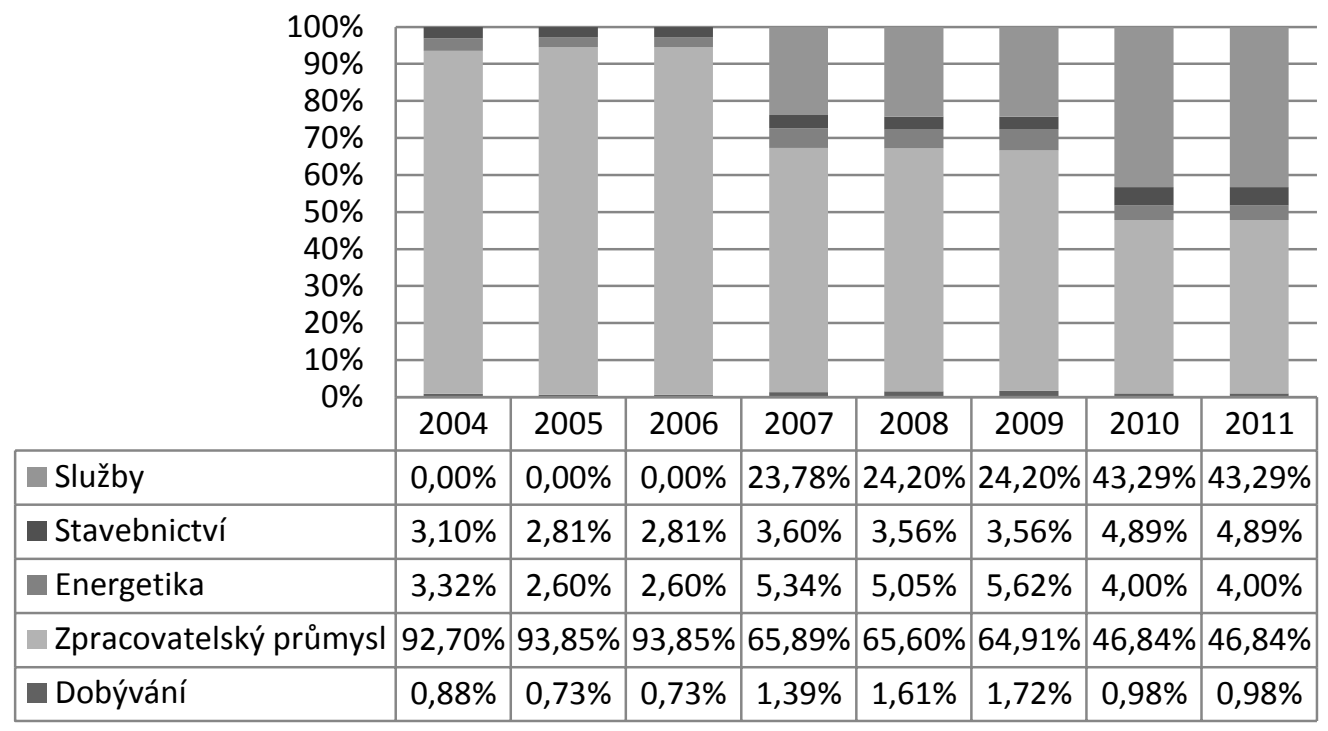

Zdroj: vlastní na podkladu oborových analýz Ministerstva průmyslu a obchodu ${ }^{3}$

Naopak u společností, které jsou vlastněny zahraničním investorem, je oproti celkovým hodnotám převaha ve zpracovatelském průmyslu, což by naznačovalo největší zájem zahraničních investorů právě o sektor zpracovatelského průmyslu.

\subsection{Vývoj vztahu debt/equity ratio a rentability vlastního kapitálu v podmínkách České republiky}

Základ analýzy se zabývá vztahem na základě korelace ukazatele ROE a ukazatele D/E ratio ve všech oborech podnikání. Obecně se z hlediska teorií kapitálové struktury řeší skutečnost, že př́liv cizího kapitálu dokáže pomoci růstu rentability vlastního kapitálu. Cílem této části je zjistit, zda je vztah rentability vlastního kapitálu a většího využití cizích zdrojů financování korelován pozitivně, nebo zda využití cizích zdrojů financování nemá na vývoj rentability vliv a zda je pro tento vztah rozhodné, zda jsou podniky ve vlastnictví domácího investora nebo investora zahraničního. Hypotéza tedy zní: větš́i využití cizích zdrojů financováni vede $k$ vyšši hodnotě rentability vlastního kapitálu bez ohledu na to, zda je majitelem podniku domácí či zahraniční investor. Tuto hypotézu by měly potvrdit hodnoty korelačního koeficientu blížící se hodnotě jedna celá. Použití korelace je jeví jako nejprůkaznější z pohledu analýzy vztahu dvou proměnných v osmiletém časovém období.

\footnotetext{
${ }^{3}$ Server of Ministry of Industry and Trade of the Czech Republic. [online] Praha, 2012 [vid. 2013-01-02] Url: http://www.mpo.cz, Finanční analýzy Ministerstva průmyslu a obchodu České republiky.
} 
Obrázek 4: Korelace rentability vlastního kapitálu a Debt/Equity ratio ve vybraných oborech podnikání s domácími a se zahraničními vlastníky

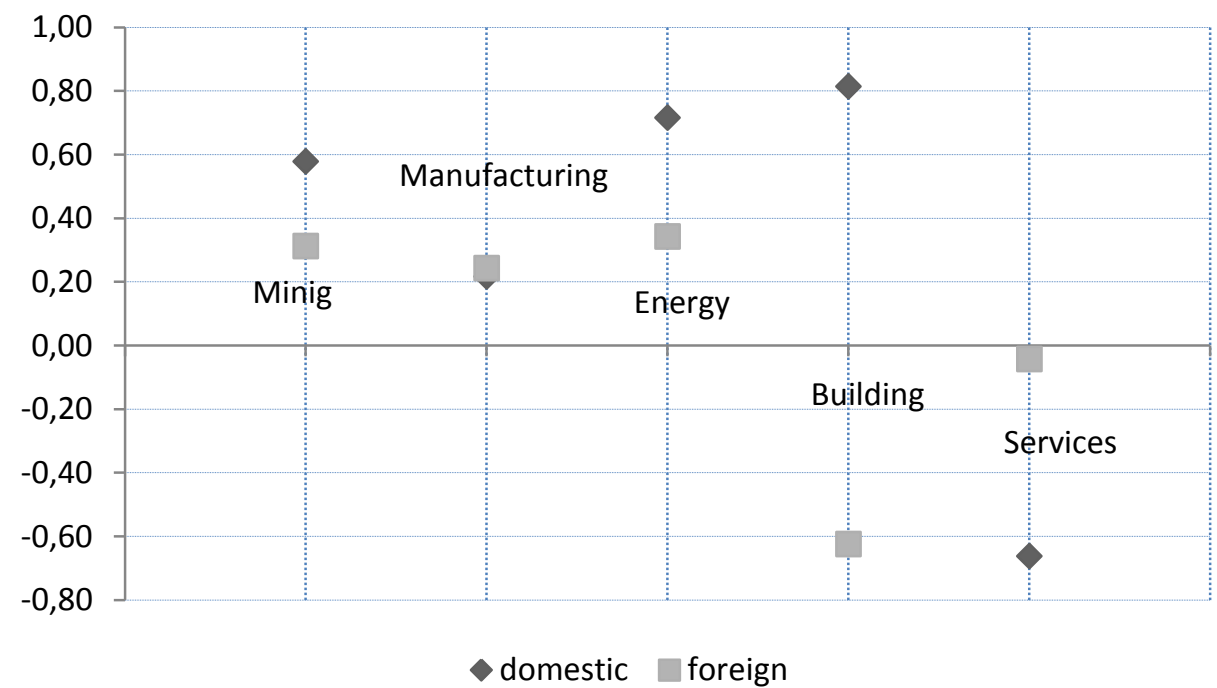

Zdroj: vlastní na podkladu oborových analýz Ministerstva průmyslu a obchodu ${ }^{4}$

Z obrázku 4 je patrné, že většina sledovaných částí vztahu ROE a D/E ratio se skutečně nachází v pásmu pozitivní korelace, neboli souběžně se vyvíjejícího vztahu. To znamená, že s růstem ochoty využít cizí zdroje financování v letech 2004 - 2011 rostla také efektivnost na úrovni vlastního kapitálu. Síla tohoto vztahu je však rozdílná. Zatímco u energetiky, stavebnictví a těžby u domácích vlastníků je možné zaznamenat velmi silnou pozitivní vazbu, tak u stavebnictví se zahraničním vlastníkem a ve službách s domácím vlastníkem je možné zaznamenat silnou negativní vazbu. Téměř nekorelovaný vztah můžeme zaznamenat u služeb se zahraničním vlastníkem. Ostatní položky zaznamenaly sice pozitivní, ale ne př́liš silnou vazbu. Z deseti různých pozorovaných skupin v letech $2004-2011$ je 7 v pásmu pozitivní korelace a tři v pásmu negativní korelace ( $\mathrm{z}$ toho jedna hodnota je sice záporná, ale velmi blízká 0 , tedy nekorelovanému vztahu).

\subsection{Vývoj vztahu tempa růstu HDP a rentability vlastního kapitálu v podmínkách České republiky}

Druhá část analýzy je postavena na vztahu vývoje hrubého domácího produktu a rentability vlastního kapitálu. Z hlediska struktury v oboru by největší míru korelace měly zaznamenat zpracovatelský průmysl a oblast služeb. Většina podniků v těchto oborech navíc lze považovat za procyklické, nebot' nejlepších výsledků hospodaření dosahují v době ekonomického růstu a nejnižších hodnot v době ekonomické krize. Opět bude zajímavé sledovat, zda vykazují odlišné chování společnosti s domácím vlastníkem a společnosti s vlastníkem zahraničním. Hypotéza této části zní: vzhledem k procykličnosti většiny odvětví by dosažené hodnoty rentability vlastního kapitálu mély vykazovat stejnou vývojovou tendenci jako vývoj hrubého domácího produktu.

\footnotetext{
4 Server of Ministry of Industry and Trade of the Czech Republic. [online] Praha, 2012 [vid. 2013-01-02] Url: http://www.mpo.cz, Finanční analýzy Ministerstva průmyslu a obchodu České republiky.
} 
Obrázek 5: Souměření hrubého domácího produktu a rentability vlastního kapitálu ve vybraných oborech podnikání s domácími vlastníky

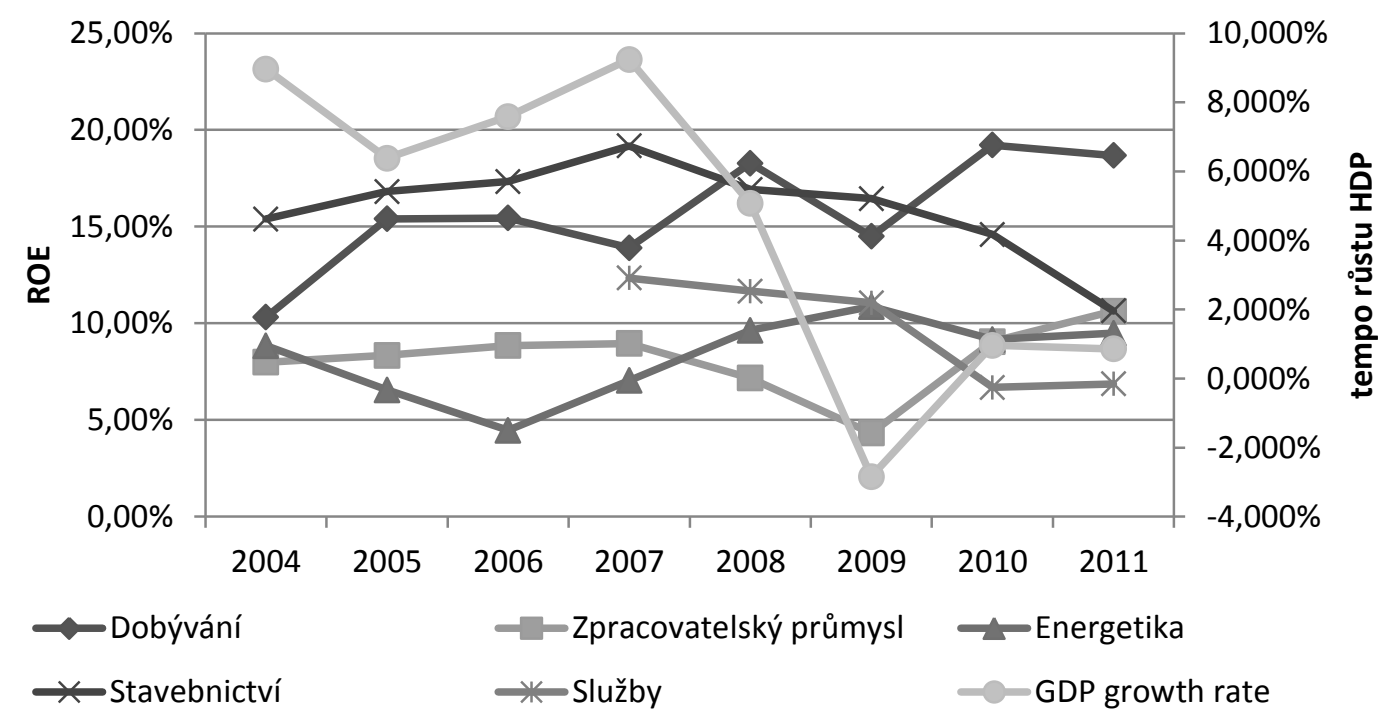

Zdroj: vlastní na podkladu oborových analýz Ministerstva průmyslu a obchodu ${ }^{5}$

Původní předpoklad, že s růstem HDP poroste i rentabilita vlastního kapitálu a že nejsilnější vazba bude u dvou největších oborů podnikání, se nepotvrdil, ale pro oblast služeb máme $\mathrm{k}$ dispozici pouze pětiletou časovou řadu, takže není možné za zcela průkaznou. Z Obrázku 5 pro podniky s domácími vlastníky je patrné, že striktně korelovaný vztah lze nalézt u hodnot stavebnictví, které kopírují pohyb tempa růstu HDP (při měření korelačního koeficientu vykázaly hodnotu 0,51 u sledovaných závislých veličin). Největší obor z hlediska počtu podniků - služby - má sice podobnou tendenci, ale reaguje méně výrazně na změnu tempa růstu (korelační koeficient 0,49). Podobnou závislost, jakou je možno zaznamenat u energetiky, vykazuje ještě zpracovatelský průmysl. Výrazně odlišnou vývojovou tendenci vykazuje energetika, v tomto kontextu je možné uvažovat o skutečnosti, že energetika není závislá jen na vývoji průmyslu, ale na relativně stabilním chování domácností z hlediska odběru energií a stabilní cenové politice (energetika vykázala měřenou závislost v hodnotě korelačního koeficientu -0,69). Podobnou tendenci ještě zaznamenáme u těžby a dobývání, což je obor podnikání, který bezprostředně souvisí s energetikou.

Budeme-li však porovnávat chování podniků s domácím vlastníkem ohledně tvorby zisku a tím i rentability vlastního kapitálu s podniky se zahraničním vlastníkem, budou zřejmé rozdíly. Zahraniční vlastník zpravidla očekává návratnost své vložené investice v kratším časovém horizontu než vlastník domácí, což se samozřejmě při vykazování zisku projeví, nebot' domácí podniky mají větší tendence $\mathrm{k}$ reinvesticím a zahraniční vlastníci na vyplácení podílů z podnikatelské činnosti. Odlišnou vývojovou tendenci lze vysledovat z následujícího Obrázku 6, který stejně jako přechozí věnuje pozornost souměření vývoje hrubého domácího produktu a rentability vlastního kapitálu.

\footnotetext{
5 Server of Ministry of Industry and Trade of the Czech Republic. [online] Praha, 2012 [vid. 2013-01-02] Url: http://www.mpo.cz, Finanční analýzy Ministerstva průmyslu a obchodu České republiky.
} 
Obrázek 6: Souměření hrubého domácího produktu a rentability vlastního kapitálu ve vybraných oborech podnikání se zahraničními vlastníky

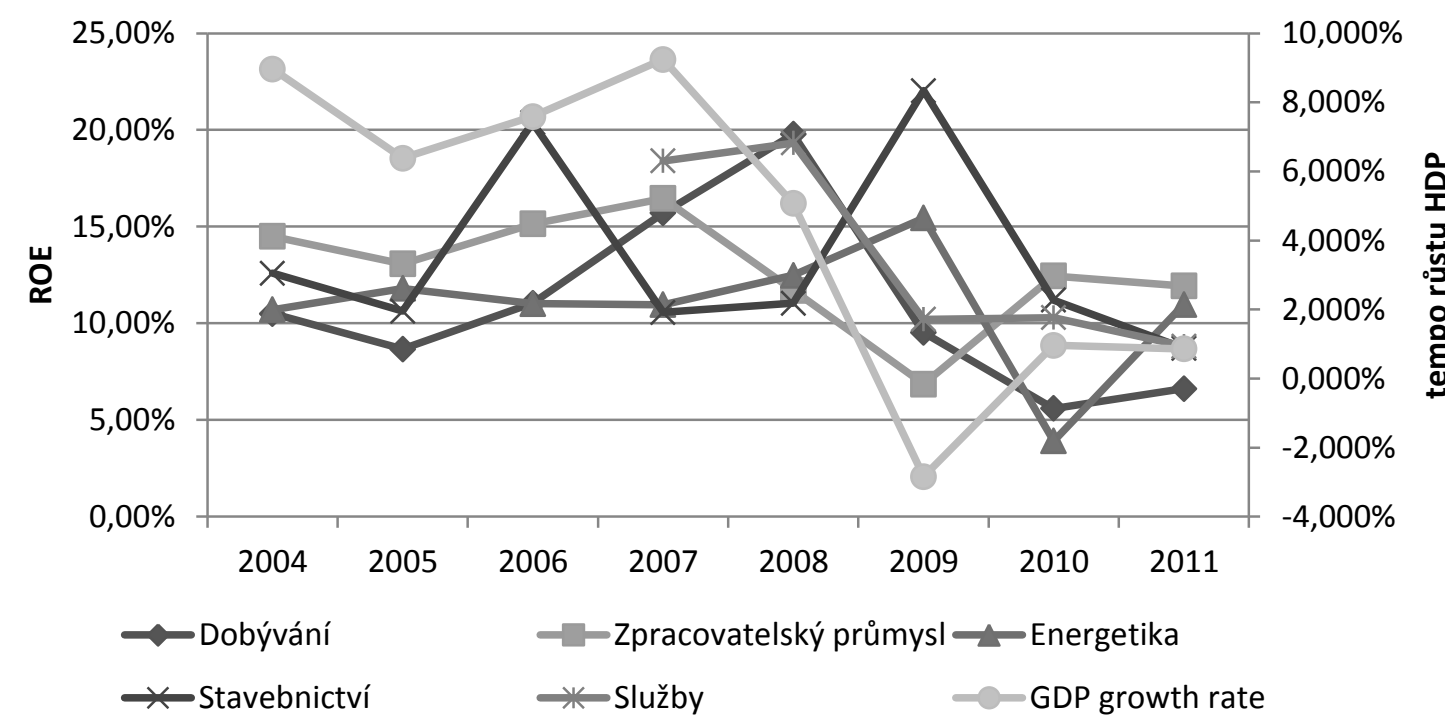

Zdroj: vlastní na podkladu oborových analýz Ministerstva průmyslu a obchodu ${ }^{6}$

U zahraničních vlastníků je možné konstatovat, že všechny sledované obory podnikání kromě stavebnictví a energetiky vykazují stejnou vývojovou tendenci, jako je vývoj hrubého domácího produktu. Nejsilnější vztah se však tentokrát potvrdil u dvou největších oborů podnikání z hlediska počtu podniků. Ve zpracovatelském průmyslu je možné vysledovat vysokou úroveň korelace na úrovni 0,89 a podobně jsou na tom služby, kde je korelační koeficient roven hodnotě 0,84 . Avšak stejně jako tomu bylo u domácích vlastníků, tak také u zahraničních vlastníků je časová řada pro sledování o tři roky kratší než u ostatních oborů podnikání. Pozitivně korelovaný vztah je možné zaznamenat ještě u dobývání a těžby. U zahraničních vlastníků v oblasti energetiky je možné zaznamenat odlišný vztah ROE a HDP oproti domácím vlastníkům, zatímco u domácích vlastníků to byl vztah téměř opačné vývojové tendence, tak u zahraničních vlastníků není zaznamenána téměř žádná korelace $(-0,07)$. Podobně je na tom stavebnictví. To u domácích vlastníků zaznamenalo nejvýraznější pozitivní vzájemný vztah, u zahraničních vlastníků je tento vztah mírně negativně korelovaný $(-0,27)$. Budeme-li brát stavebnictví jako obor, který svědčí o budoucí situaci v celkové ekonomice, pak bychom museli na základě ekonomických výsledků konstatovat, že z tohoto pohledu není krize zdaleka zažehnána. (Růčková, 2012)

\section{Závěr}

V článku byly formulovány dvě základní hypotézy. První hypotéza - větší využití cizích zdrojů financování vede k vyšší hodnotě rentability vlastního kapitálu bez ohledu na to, zda je majitelem podniku domácí či zahraniční investor - byla naplněna pouze u tří z pěti analyzovaných oborů podnikání. Hypotéza byla podpořena ve zpracovatelském průmyslu, energetice a těžbě a dobývání. Ostatní části hypotézu nepodpoří, protože služby vykázaly opačnou vývojovou tendenci bez ohledu na vlastníky podniku, a stavebnictví s růstem použití cizího kapitálu vykazuje růst ROE pouze u podniků s domácími vlastníky. Vzhledem k tomu, že do analýzy spadají podniky s více než 100 zaměstnanci, pak je možné zároveň konstatovat, že byla potvrzena i myšlenka, formulovaná v empirické evidenci, že existuje u velkých podniků větší ochota k využívání a preferování vlastního kapitálu před kapitálem cizím. Tuto

\footnotetext{
${ }^{6}$ Server of Ministry of Industry and Trade of the Czech Republic. [online] Praha, 2012 [vid. 2013-01-02] Url: http://www.mpo.cz, Finanční analýzy Ministerstva průmyslu a obchodu České republiky.
} 
myšlenku nepotvrdilo pouze stavebnictví, v němž se dluhové financování využívá ve významnější míře.

Druhá hypotéza - vzhledem k procykličnosti většiny odvětví by dosažené hodnoty rentability vlastního kapitálu měly vykazovat stejnou vývojovou tendenci jako vývoj hrubého domácího produktu - byla potvrzena u zahraničních vlastníků v oborech těžba a dobývání, zpracovatelský průmysl a služby a u domácích vlastníků u zpracovatelského průmyslu, stavebnictví a ve službách. Hypotéza nebyla potvrzena u domácích vlastníků u těžby a dobývání a u energetiky a u zahraničních vlastníků u energetiky a stavebnictví.

Z výše uvedeného je zřejmé, že na odvětvové úrovni nelze jednoznačně potvrdit, že zahraniční vlastnictví je kladně provázáno s efektivitou a že př́mé zahraniční investice vykazují na mikroekonomické úrovni významně pozitivnější vliv než domácí investice. Rozdíl v efektivitě mezi podniky vlastněnými domácími a zahraničními investory a to jak vzhledem $\mathrm{k}$ efektivitě využívání kapitálu, tak $\mathrm{k}$ výkyvům $\mathrm{v}$ souvislosti e ekonomickým vývojem nelze označit za jednoznačný.

\section{Literatura}

[1] ARNDT, CH. and A. MATTES, 2008. The Impact of Inward FDI and Foreign Ownership on the. Performance of German Multinational Firms [online]. Graz: Karl Franzens Universität, [vid. 2013-01-02]. Available from: <http://www.unigraz.at/socialpolitik/papers/Mattes.pdf>.

[2] DEMEL, J. and Z. POTUŽÁKOVÁ, 2012. FDI and the Liberec Region: The case of the labour market. E\&M Economics and Management, XV(4), 4-18. ISSN 1212-3609.

[3] DWORIN, L., 1990. Transfer pricing issues. National Tax Journal, 43, 285-291. ISSN 0028-0283.

[4] Economic survey of Europe No. 1. [online]. New York: United Nations, 2001. [vid. 2013-01-02]. Dostupné z http://www.unece.org/fileadmin/DAM/ead/pub/ 011/011_0.pdf.

[5] GELÜBCKE, J. P. W., 2011. Foreign Ownership and Firm Performance in German Services: First Evidence based on Official Statistics [online]. Lueneburg: Leuphana University Lueneburg, [cit. 2013-01-02]. Dostupné z: http://204.3.197.155/ETSG2011/Papers/Geluebcke.pdf.

[6] HANOUSEK, J., E. KOČENDA and M. MAŠIKA, 2012. Firm efficiency: Domestic owners, coalitions, and FDI. Economic Systems, 36(4), 471-486. ISSN 0939-3625.

[7] HANOUSEK, J., E. KOČENDA and J. ŠVEJNAR, 2005. Origin and Concentration: Corporate Ownership, Control and Performance [online]. Prague: CERGE WP. ISSN 1211-3298. [vid. 2013-03-15]. Dostupné z: http://www.cerge-ei.cz/pdf/wp/Wp259.pdf.

[8] HRDÝ, M., 2011. Optimalizace kapitálové struktury konkrétního podniku věc teoreticky či prakticky možná? Český finanční a účetní časopis, 6(1), 19 - 32. ISSN $1802-2200$

[9] JAROLÍM, M., 2000. Foreign Direct Investment and Productivity of Firms. Czech Journal of Economics and Finance, 50(9), 478-487. ISSN 0015-1920.

[10] JENSEN, M. C., 1986. Agency costs of free cash flow, corporate finance and takeovers. American Economic Review, 76, s. 327. 
[11] JURAJDA, Š. and J. STANČÍIK, 2009. Foreign Ownership and Corporate Performance: The Czech Republic at EU Entry [online]. CERGE EI Prague: CERGE WP. ISSN 1211-3298. [vid. 2013-03-15]. Dostupné z: http://www.cergeei.cz/pdf/wp/Wp389.pdf.

[12] MYERS, S. C., 1984. The Capital Structure Puzzle. Journal of Finance, 39(3), 575-592. ISSN 1540-6261.

[13] Př́mé zahraniční investice za rok 2009 [online]. Praha, 2010. [cit. 2012-02-22]. Dostupné Z: www.cnb.cz/ cs/statistika/platebni_bilanc/stat/publikace_pb/pzi/ PZI_2009_CZ.pdf.

[14] ROUBÍČKOVÁ, M., 2008. Vliv corporate governance na dividendovou politiku akciových společností v České republice. Corporate governance v České republice. Praha: Professional Publishing, pp. 73-100. ISBN 978-80-86946-0.

[15] ROUBÍČKOVÁ, M., 2012. Vliv institucionálního sektoru na vývoj vybraných ukazatelů. Scientific Papers of the University of Pardubice, S. D, No 25. Pardubice: University of Pardubice, pp. 147 - 156. ISSN 1211-555X.

[16] RƯČKOVÁ, P., 2012. The relationship of liquidity and profitability in financial management of corporations in conditions of the Czech Republic. In: Karpatský logistický kongres. Ostrava: EkF, VŠB-TU Ostrava. ISBN 978-80-87294-33-8.

[17] RŮČKOVÁ, P., 2012. Profitability as Basic Criterion of Efficient Management in Context of Crisis Development. In: Proceedings of the 13th International Conference on Finance and Banking. Karviná: SU OPF, p. 313 -230. ISBN 978-80-7248-753-0.

[18] SAKAKIBARA, M. and H. YAMAWAKI, 2005. What Determines the Profitability of Foreign Direct Investment? A Subsidiary-Level Analysis of Japanese Multinationals [online]. Claremont: Claremont Graduate University. [vid. 2013-01-02]. Dostupné z: http://www.cgu.edu/PDFFiles/Faculty/Yamawaki/Profit\%2012-14-05.pdf.

[19] Server of Ministry of Industry and Trade of the Czech Republic [online]. Praha, 2012 [vid. 2013-01-02] Url: http://www.mpo.cz, Finanční analýzy Ministerstva průmyslu a obchodu České republiky.

[20] SPĚVÁČEK, V., 2010. Sektorová analýza vývoje české ekonomiky [online]. [vid. 201203-23]. Dostupné z: https://is.muni.cz/ do/econ/soubory/oddeleni/ centrum/papers/16Spevacek.pdf.

[21] STULZ, R., 1990. Managerial dicreation and optimal financing policies. Journal of Financial Economics, 26(5). ISSN 0304-405X.

[22] SZANYI, M., 1998. Foreign Direct Investments in Small Business in Transition Economies [online]. Warsaw: Central European University. ISBN 83-7178-087-7. [vid. 2013-03-15]. Dostupné z: http://www.isn.ethz.ch/isn/DigitalLibrary/Publications/Detail/?ots591=0c54e3b3-1e9c-be1e-2c24a6a8c7060233\&lng=en\&id=128892.

[23] YASAR, M. and C. J. M. PAUL, 2007. Firm Performance and Foreign Direct Investment: Evidence from Transition Economies. Economics Bulletin [online]. Vol. 15, No. 21, pp. 1-11. [vid. 2013-03-12]. Dostupné z: <http://www.accessecon.com/pubs/EB/2007/Volume15/EB-07O50003A.pdf>. 